\title{
NOTES
}

Limnol. Oceanogr., 27(5), 1982, 950-954

(C) 1982, by the American Society of Limnology and Oceanography, Inc.

\section{Mannitol-fermenting bacteria as evidence for export from kelp beds}

Abstract-Mannitol-fermenting bacteria are used to trace export from kelp beds along the west coast of the Cape Peninsula, South Africa. Under active upwelling conditions these bacteria are found in the water $4.5 \mathrm{~km}$ offshore and are probably exported to a distance of at least $8-9 \mathrm{~km}$. During the relaxation phase of upwelling the kelp bed water is contained in a narrow band close to shore and no mannitolytic bacteria are found $4.5 \mathrm{~km}$ offshore.

Mucilage released into the water during fragmentation of kelp fronds (Hatcher et al. 1977; Johnston et al. 1977) can support a bacterial production of 14-18 g dry $\mathrm{wt} \cdot \mathrm{m}^{3} \cdot \mathrm{yr}^{\mathrm{L}}$ in nearshore, kelp bed waters of the west coast of the Cape Peninsula, South Africa (e.g. Linley et al. 1981; Linley and Newell 1981). The principal primary photosynthetic product of the two dominant kelp species in the system, Laminaria pallida (Grev.) J. Agr. and Ecklonia maxima Osbeck, is the polyol D-mannitol, which accounts for as much as $77 \%$ of the free reducing sugars and polyols in the mucilage (Newell et al. 1980; Stuart et al. 1981).

Waters adjacent to the Cape Peninsula are subject to strong upwelling, and offshore transport of surface water can be vigorous (Andrews and Hutchings 1980; Field et al. 1980); the mucilage products are transported offshore under these conditions. Quantitative estimation of this transport is complicated by both the large dilution factors involved and the possible rapid utilization of the kelp-derived carbohydrates by bacteria in the water (Lucas et al. 1981; Newell and Lucas 1981). Preliminary studies by F. Robb (pers. comm.) indicate that a large proportion of the kelp bed bacteria are adapted to the rapid utilization of carbohydrates produced by kelp. Mannitol in particular is metabolized extremely fast by such or- ganisms (see also Lucas et al. 1981; Newell and Lucas 1981). This suggested that the presence of substrate-specific bacteria might be used to follow the movement of the water and to investigate the transport of material; we discuss here aspects of such an approach using mannitol-fermenting bacteria. We thank F. Robb and W. Petrie for assistance throughout this study, and J. G. Field for critical reading of the manuscript. Financial assistance from the South African National Committee for Oceanographic Research and the National Research Institute for Oceanology of the CSIR is acknowledged.

The study area at Oudekraal, Cape Peninsula $\left(33^{\circ} 59^{\prime} \mathrm{S}, 18^{\circ} 21^{\prime} \mathrm{E}\right)$, is described in detail by Velimirov et al. (1977) and Field et al. (1980). Water samples were taken at six stations along a transect normal to the coastline (Fig. 1). Stations 1,2 , and 3 were in the inshore, mediate, and offshore localities of the kelp bed as defined by Velimirov et al. (1977) and stations 4,5 , and 6 over sand bottom at distances of $0.9,2.0$, and $4.5 \mathrm{~km}$ from the coast.

Samples were collected just beneath the surface from a boat with 5-liter NIO bottles at stations 3-6 and by a diver at stations 1 and 2 to prevent disturbance of the kelp fronds in shallow water. Replicate 20 -ml aliquots of the samples were dispensed into sterile glass bottles, kept in an insulated cool box, transported to the laboratory within $3 \mathrm{~h}$, and then kept at $4^{\circ}-5^{\circ} \mathrm{C}$. Plate counts of bacteria in seawater samples kept in this way remained constant for at least 2 weeks.

The incubation medium used consisted of $1 \%$ peptone (Oxoid) and $1 \%$ D-mannitol (Merck) in $0.2-\mu \mathrm{m}$-filtered seawater plus $2 \%$ of a $0.01 \%$ phenol red indicator 


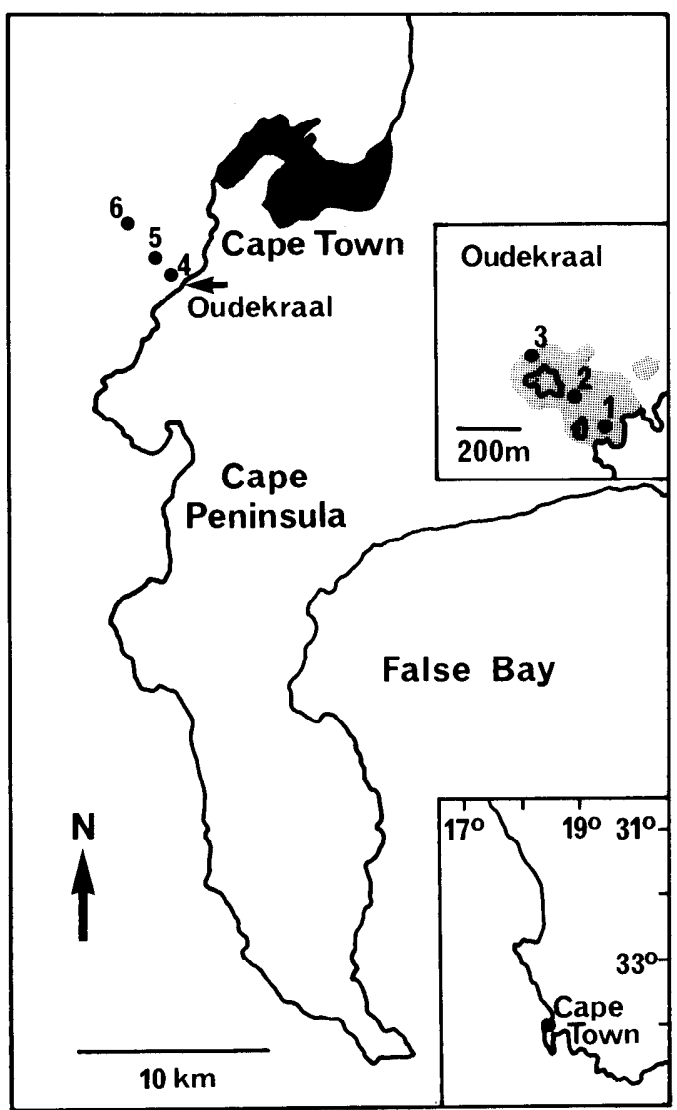

Fig. 1. Cape Peninsula showing study area at Oudekraal and stations $4(0.9 \mathrm{~km}), 5(2.0 \mathrm{~km})$, and $6(4.5 \mathrm{~km})$ of the transect. Inserts show study area on west coast of South Africa and detail of study site; shaded area represents extent of kelp bed at Oudekraal.

solution. The $\mathrm{pH}$ was adjusted to 7.9 , that of the seawater at Oudekraal. Two milliliters of this medium was pipetted into each 7-ml Bijou bottle and autoclaved.
The water samples were treated as follows; all were run in duplicate at $20^{\circ} \mathrm{C}$. One milliliter was pipetted into a Bijou bottle of sterile medium on the day after sampling and the time noted for the indicator to turn yellow ( $\mathrm{pH} 6.8)$, indicating the production of acid by bacterial fermentation of mannitol. This time is referred to below as "turning time."

A sample of natural seawater, diluted with sterile seawater to yield between 30 and 120 colonies, was streaked onto solid agar (Difco) plates (Oppenheimer and ZoBell 1952). Total numbers of bacteria in seawater samples checked by acridine orange direct counts after filtration onto $0.2-\mu \mathrm{m}$ Nuclepore polycarbonate filters (Hobbie et al. 1977; Linley et al. 1981) gave results similar to plate counts.

A sample from each colony on the agar plate was transferred to a Bijou bottle containing incubation medium $(2 \mathrm{ml})$ to test for fermentation of mannitol, and the percentage of mannitolytic bacteria for each station was thus calculated.

During the study period in February 1981 the variety of hydrographic conditions ranged from active upwelling, with associated low water temperatures, to the relaxation phase of the upwelling cycle with higher water temperatures. Carter (1982) estimated that active upwelling is characteristic of the study site for about $51 \%$ of the year, mainly in spring and summer (Andrews and Hutchings 1980). Turning times differ under the different hydrographic conditions, being fairly uniform along the transect during active upwelling but exhibiting a strong gradient during the relaxation phase (Table 1).

Table 1. "Turning times" (defined in text) in hours measured for each station along a 4.5-km transect at Oudekraal, Cape Peninsula, for entire study period. Active upwelling was characterized by strong offshore winds $\left(18-20 \mathrm{~m} \cdot \mathrm{s}^{-1}\right)$ and uniformly low surface water temperature, relaxation by light onshore winds $\left(1 \mathrm{~m} \cdot \mathrm{s}^{-1}\right)$ and higher, variable surface water temperatures.

\begin{tabular}{|c|c|c|c|c|c|c|c|c|c|}
\hline \multirow[b]{2}{*}{ Day } & & \multicolumn{6}{|c|}{ Station No. } & \multirow{2}{*}{$\begin{array}{l}\text { Surface temp } \\
\text { range }\left({ }^{\circ} \mathrm{C}\right)\end{array}$} & \multirow[b]{2}{*}{ Upwelling phase } \\
\hline & & 1 & 2 & 3 & 4 & 5 & 6 & & \\
\hline 1 & 19 Feb & 13.50 & 13.50 & 15.75 & 17.70 & 19.75 & 19.75 & $15.0-16.0$ & relaxation \\
\hline 2 & $20 \mathrm{Feb}$ & 14.00 & 13.00 & 13.00 & 14.00 & 14.00 & 14.00 & $12.0-13.0$ & early active \\
\hline 3 & $21 \mathrm{Feb}$ & 13.00 & 14.00 & 14.00 & 14.00 & 14.00 & 14.00 & $10.0-11.0$ & active upwelling \\
\hline 4 & $22 \mathrm{Feb}$ & 14.50 & 14.30 & 15.00 & 15.50 & 16.00 & 15.50 & $12.0-15.0$ & early relaxation \\
\hline 5 & 23 Feb & 12.75 & 11.25 & 12.25 & 12.75 & 17.25 & 22.75 & $12.5-14.0$ & relaxation \\
\hline 6 & $25 \mathrm{Feb}$ & 13.25 & 12.75 & 12.25 & 14.25 & 15.25 & 14.25 & $10.5-11.5$ & active upwelling \\
\hline
\end{tabular}


Table 2. Number of bacterial colonies isolated from seawater samples during active upwelling (day 3) and relaxation phase of upwelling cycle (day 5) for each station along a $4.5-\mathrm{km}$ transect at Oudekraal, Cape Peninsula, and number of colonies showing acid end products after incubation in $1 \%$ mannitol medium (i.e. mannitolytic activity of bacteria).

\begin{tabular}{ccc}
\hline \hline Sta. No. & $\begin{array}{c}\text { Total No. } \\
\text { colonies on } \\
\text { agar plate }\end{array}$ & $\begin{array}{c}\text { No. colonies } \\
\text { showing acid } \\
\text { fermentation } \\
\text { of mannitol }\end{array}$ \\
\hline Day 3 & & \\
1 & 30 & 6 \\
2 & 114 & 72 \\
3 & 50 & 30 \\
4 & 30 & 16 \\
5 & 50 & 24 \\
6 & 49 & 15 \\
Day 5 & & \\
1 & 44 & 31 \\
2 & 43 & 37 \\
3 & 43 & 42 \\
4 & 80 & 73 \\
5 & 49 & 27 \\
6 & 37 & 0 \\
\hline
\end{tabular}

During the relaxation phase when surface water flow is onshore a strong gradient of mannitolytic bacteria was also recorded (Table 2, Fig. 2). Whereas water sampled in or close to the kelp bed contained nearly $100 \%$ mannitolytic bacteria, this percentage dropped to half at the $2-\mathrm{km}$ station and no mannitol-fermenting bacteria were found at the farthest, $4.5-\mathrm{km}$ station. Evidently during the relaxation phase the nearshore water is contained in a rather narrow band and material from the kelp bed is localized in the inshore region. Total bacterial numbers (AODC) ranged from 4.4 to $10.3 \times$ $10^{6} \cdot \mathrm{ml}^{-1}$ with about $4.4 \times 10^{6} \cdot \mathrm{ml}^{-1}$ at both stations 5 and 6 . This indicates that the mannitolytic activity gradient is due to a change in the composition of the microheterotrophic community, not merely to a decrease in bacterial standing stock with distance offshore.

During active upwelling, with surface water moving offshore, the percentage of mannitolytic bacteria remained fairly high along the entire transect. Up to $30 \%$ of the plate count bacteria at the station 4.5 $\mathrm{km}$ offshore were mannitolytic and were

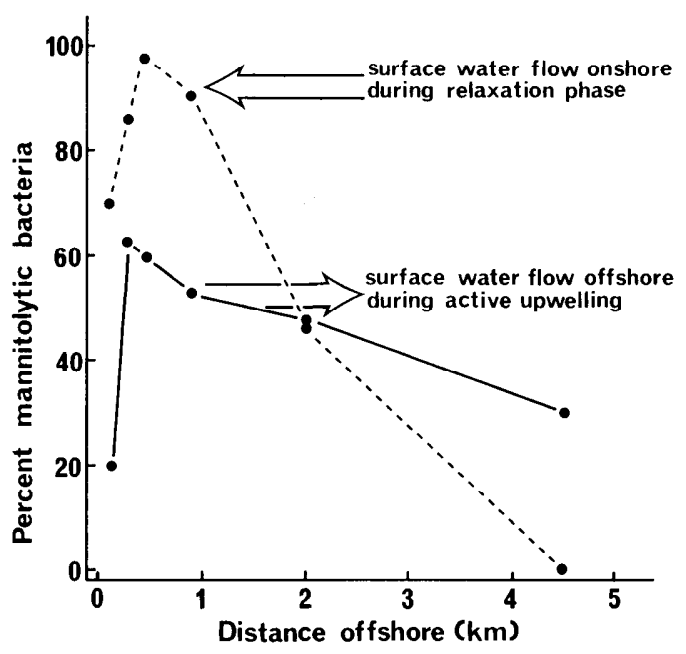

Fig. 2. Percentage of mannitolytic bacteria at six stations along a transect normal to shoreline measured during two hydrographic conditions. Stations 1-3 were in the kelp bed, stations $4-6$ over sand bottom. Solid line-active upwelling (21 February 1981); dashed line-relaxation phase (23 February 1981).

thus probably derived from the kelp bed area (Fig. 2). Since mannitol fermenters in the kelp bed form about $60 \%$ of the microbial community, this indicates that the bacteria are diluted two times during transport from the kelp bed to the $4.5-\mathrm{km}$ station under active upwelling conditions. The upwelling curve in Fig. 2 suggests that mannitolytic bacteria could be found up to 8 or $9 \mathrm{~km}$ offshore; this distance could be even greater during periods of sustained upwelling. Some organic material from the kelp is undoubtedly also transported this far offshore, but the presence of the bacteria does not give us information about how much.

An interesting feature of our results is that the proportion of mannitolytic bacteria at the inshore stations was markedly lower during active upwelling than during the relaxation phase. This seems to suggest that the upwelling water which is transported through the inshore region already contains a bacterial population but that this population lacks the ability to ferment mannitol. These bacteria may be forms present in deeper, offshore waters 
which are associated with the degradation of sinking organic matter derived mainly from phytoplankton. Station 1 consistently had rather low proportions of mannitolytic bacteria. The sheltered nature of this station probably results in less erosion of kelp fronds and in reduced release of kelp-derived dissolved organic matter (DOM), leading to a smaller proportion of mannitolytic bacteria. This hypothesis was confirmed by the presence of lower concentrations of DOM at station 1 than elsewhere along the transect.

The data show the existence of a specialized kelp bed bacterial community characterized by its ability to ferment mannitol from kelp. Offshore this community is replaced by bacteria which cannot ferment mannitol, as indicated by the low proportions of mannitolytic bacteria in offshore waters, particularly during the relaxation phase of the upwelling cycle (Fig. 2; see also the consistently longer turning times of offshore samples under relaxation conditions in Table 1).

Marine bacteria are often abundant and can use organic material rapidly (Linlcy and Newell 1981; Newell and Lucas 1981). These products may thus be present in the water for very brief periods and DOM concentrations are likely to represent only residual amounts, making chemical measurements at low concentrations difficult. Specialized nearshore bacteria are likely to be exported in bursts with the pulsing of nearshore currents. Bioassay of rapidly responding specialized bacteria appears to be a method well suited to detecting water originating from kelp beds or other macrophyte-dominated nearshore regions.

K. Koop

Zoology Department

University of Cape Town

Rondebosch 7700

South Africa

\section{R. A. Carter}

National Research Institute for Oceanology

P.O. Box 320, Stellenbosch

South Africa
R. C. Newell

Institute for Marine Environmental

Research

Prospect Place, The Hoe

Plymouth P11 3DH, U.K.

\section{References}

ANDREws, W. R., AND L. Hutchings. 1980. Upwelling in the southern Benguela current. Prog. Oceanogr. 9: 1-81.

Carter, R. A. 1982. Phytoplankton biomass and production in a southern Benguela kelp bed system. Mar. Ecol. Prog. Ser. 8: 9-14.

Field, J. G., C. L. Griffiths, E. A. Linley, R. A. CARTER, AND P. ZUUTENDYK. 1980. Upwelling in a nearshore marine ecosystem and its biological implications. Estuarine Coastal Mar. Sci. 11: 133-150.

Hatcher, B. G., A. R. Chapman, and K. H. ManN. 1977. An annual carbon budget for the kelp Laminaria longicruris. Mar. Biol. 44: 85-96.

HobbIE, J. E., R. T. DALEY, AND S. JASPER. 1977. Use of Nuclepore filters for counting bacteria by fluorescence microscopy. Appl. Environ. Microbiol. 33: 1225-1228.

Johnston, C. S., R. G. Jones, And R. D. Hunt 1977. A seasonal carbon budget for a laminarian population in a Scottish sea loch. Helgol. Wiss. Meeresunters. 30: 527-545.

Linley, E. A., AND R. C. Nfwfi,l. 1981. Microheterotrophic communities associated with the degradation of kelp debris. Kiel. Meeresforsch. Sonderh. 5: 345-355.

AND S. Bosma. 1981. Heterotrophic utilisation of mucilage released during fragmentation of kelp (Ecklonia maxima and Laminaria pallida). 1. Development of microbial communities associated with the degradation of kelp mucilage. Mar. Ecol. Prog. Ser. 4: $31-41$.

LuCAS, M. I., R. C. Newell, AND B. Velimirov. 1981. Heterotrophic utilisation of mucilage released during fragmentation of kelp (Ecklonia maxima and Laminaria pallida). 2. Differential utilisation of dissolved organic components from kelp mucilage. Mar. Ecol. Prog. Ser. 4: 43-55.

Newell, R. C., AND M. I. LuCAS. 1981. The quantitative significance of dissolved and particulate organic matter released during fragmentation of kelp in coastal waters. Kiel. Meeresforsch. Sonderh. 5: 356-369.

-, , B. Velimirov, AND L. J. SeIDERER. 1980. The quantitative significance of dissolved organic losses following fragmentation of kelp (Ecklonia maxima and Laminaria pallida). Mar. Ecol. Prog. Ser. 2: 45-59.

OpPenheimer, C. H., AND C. E. ZoBell. 1952. The growth and viability of sixty-three species of marine bacteria as influenced by hydrostatic pressure. J. Mar. Res. 11 : 10-18.

Stuart, V., M. I. LuCAS, AND R. C. Neweli.. 1981. Heterotrophic utilisation of particulate matter 
from the kelp Laminaria pallida. Mar. Ecol. Prog. Ser. 4: $337-348$.

Velimirov, B., J. G. Field, C. L. Griffiths, AND P. ZOUTENDYK. 1977. The ecology of kelp bed communities in the Benguela upwelling sys- tem. Analysis of biomass and spatial distribution. Helgol. Wiss. Meeresunters. 30: 495-518.

Submitted: 10 July 1981 Accepted: 2 March 1982

\section{Preliminary observations on the effects of flooding and desiccation upon the net photosynthetic rates of high intertidal estuarine sediments ${ }^{1}$}

Abstract-Measurements of gaseous $\mathrm{CO}_{2}$ exchange from high intertidal estuarine sediments revealed that net photosynthetic rates of moist, unflooded sediments were maximal. Flooding of moist sediments with 1-2 $\mathrm{mm}$ of agitated seawater reduced net photosynthetic rates by $48-66 \%$. When moist sediments lost $10-15 \%$ of their water content $\mathrm{CO}_{2}$ uptake decreased, and high rates of $\mathrm{CO}_{2}$ evolution were observed later as water losses continued.

To our knowledge there have been no controlled experiments testing the effects of flooding and desiccation on gas exchange rates of sediment samples from intertidal zones in estuarine sediments. The water content of intertidal sediment varies with wetland topography, tidal regimen, sediment type, and climatefactors which vary with location and season. Within the same wetland the tidal regimen varies daily leaving portions of sediment flooded or exposed for varying periods. The accuracy of our estimates of wetland sediment productivity thus depends upon the precision with which responses of the biota to periodic flooding and desiccation are accounted for. Knowledge of such responses is also important in evaluating the efficacy of wetland restoration efforts and some of the effects of wetland development. Since the methodology commonly used in estimating productivity involves flooding of sed-

\footnotetext{
${ }^{1}$ This work was partially supported by the University of California Sea Grant College Program (grant R/CZ-52) and by a University of California Faculty Research Grant to B.E.M.
}

iments, our knowledge of the actual effects of flooding and desiccation is scant and even conflicting (Leach 1970; Joint 1978). The availability of suitable gas exchange equipment capable of yielding continuous measurements of gas exchange rates and environmental parameters under controlled conditions led us to undertake a laboratory study of the effects of flooding and desiccation on moist sediments from the high intertidal.

We thank M. Quammen and G. Shaffer who collected some of the cores used in this study, K. MacDonald and P. Nobel for suggestions and calculations, and two anonymous reviewers for constructive criticisms.

Sediment samples were collected from the high intertidal in the east arm of Mugu Lagoon, U.S. Navy Pacific Missile Test Center, about $15 \mathrm{~km}$ south of Oxnard, Ventura County, California. The moist core samples were taken by pressing a glass cylinder $(28-\mathrm{mm}$ i.d. $\times 11 \mathrm{~mm}$ high) into the sediment until the surface was 1-2 mm below the top edge of the cylinder. A thin piece of plastic was then pushed across the bottom of the cylinder through the sediment and the assembly lifted vertically, maintaining the integrity of the core. The cylinder and core were placed in a small plastic petri dish (i.d. of the bottom, $35 \mathrm{~mm}$; height, $10 \mathrm{~mm}$ ) and returned promptly to the laboratory where the space between the outer edge of the glass cylinder and the inner edge of the petri dish bottom was filled with seawater to keep the cores saturated. The cores 